\title{
Osmotic flows across the blood-joint barrier
}

\author{
J R LEVICK AND A D KNIGHT
}

From the Department of Physiology, St George's Hospital Medical School, London

SUMMARY The effective osmotic pressure across the blood-joint barrier is a key factor $\vec{\circ}$ controlling synovial fluid volume and joint effusions. The effect of plasma colloid osmotic $\overrightarrow{\vec{H}}$ pressure (COP) on trans-synovial flow was studied directly in rabbit knees expanded by intra-articular fluid infusion. The synovial microcirculation was perfused with blood of varying $\frac{\varrho}{\circ}$ COP. Absorption of fluid from the joint cavity was a linear function of COP; but albumin COP was only $78 \%$ effective across the blood-joint interface. Hyperosmolar solutions of small solutes (e.g., glucose) generated transient osmotic flows across the blood-joint barrier, but far less effectively than albumin. The hydraulic permeability of synovium increased at pathological ${ }^{\perp}$ intra-articular pressures-a phenomenon of potential importance to effusion kinetics.

Key words: osmotic pressure, synovial absorption, fluid exchange.

Synovial fluid is derived primarily from plasma, and disturbances in the balance of forces between plasma and the joint cavity can create large clinical effusions. Fluid movement between blood and the joint cavity is considered to obey Starling's hypothesis, ${ }^{,}$which treats the intervening tissues ('blood-joint barrier') as a semipermeable membrane. The quintessential feature of the hypothesis is that flow should be governed by the osmotic pressure of plasma proteins (colloid osmotic pressure, COP). Certain clinical observations provide indirect support for osmosis across the blood-joint barrier. For example, replacement of a protein-rich knee effusion by an equal volume of saline causes a net absorption of fluid from the joint cavity. ${ }^{2}$ Transsynovial osmotic effects, however, have never been measured. Here the effect of plasma osmotic pressure, both colloid and 'crystalloid', (i.e., small solutes) upon trans-synovial fluid exchange was investigated directly in rabbit knees. The study also assessed the osmotic reflection coefficient of the blood-joint barrier to protein-a coefficient which characterises the molecular selectivity of the barrier.

\section{Materials and methods}

To obtain full control over hydraulic and osmotic pressures on each side of the blood-joint barrier the cavity of the rabbit knee was cannulated and infused

Accepted for publication 3 March 1987.

Correspondence to Dr J R Levick, Department of Physiology, St George's Hospital Medical School, London SW17 ORE. with Krebs' solution at a known hydrostatic pressure; and the synovial microcirculation was perfused with blood of known COP at controlled pressures from one of two extracorporeal pump-oxygenator circuits, via the cannulated abdominal aorta. Perfu- $\frac{\circ}{\circ}$ sion of the knee in isolated rabbit hindquarters has been fully described previously. ${ }^{3}$ The essential $\vec{\partial}$ features (Fig. 1) were as follows.

ARTERIAL PRESSURE ( $\left.P_{A}\right)$

Pressure was generated by a Harvard peristaltic pump; regulated by a Starling resistor; and measured by a Gould-Statham pressure transducer. The 3 blood was equilibrated with $95 \% \mathrm{O}_{2}-5 \% \mathrm{CO}_{2}$ in a foam exchanger and maintained at $36-39^{\circ} \mathrm{C}$ by a윽 heat exchange coil. Control pressures were $80-100$ $\mathrm{mmHg}$.

VENOUS PRESSURE ( $\left.P_{V}\right)$

A cannula in the inferior vena cava drained into an open drop chamber whose height governed venous pressure $\left(\mathrm{P}_{\mathrm{V}}\right)$ (control level $\left.2 \mathrm{cmH}_{2} \mathrm{O}\right)$. This was recorded by a Gould-Statham transducer.

SYNOVIAL CAPILLARY PRESSURE（ $\left.\mathbf{P}_{\mathrm{C}}\right)$ Synovial capillary pressure was calculated from $P_{A}$, $\mathbf{P}_{\mathrm{V}}$, and the precapillary to postcapillary resistance ${ }^{-}$ ratio. ${ }^{3} \mathrm{P}_{\mathrm{C}}$ was $23-48 \mathrm{cmH}_{2} \mathrm{O}$ at control $\mathrm{P}_{\mathrm{A}}, \mathrm{P}_{\mathrm{V}}$

PRESSURE IN THE JOINT CAVITY ( $\left.P_{J}\right)$

Pressure in the joint cavity was recorded by an intraarticular (IA) $21 \mathrm{G}$ cannula in the suprapatellar 


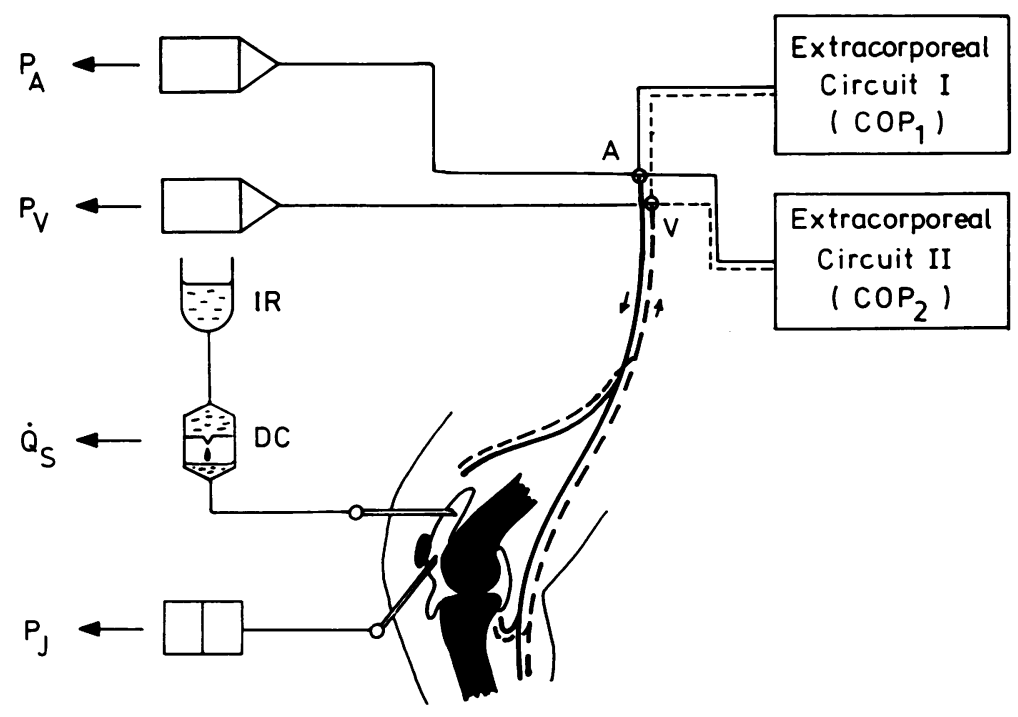

Fig. 1 Schematic representation of artifically perfused knee of isolated rabbit hindquarters. The joint was perfused via tap $A$ connected to a cannula in the abdominal aorta; and drained via tap $V$ connected to the abdominal vena cava. The two extracorporeal circuits contained bloods of different colloid osmotic pressure and consisted of peristaltic pump, foam oxygenator, heat exchanger, bubble trap, Starling resistor, and venous drop chamber. Arterial pressure $\left(P_{A}\right)$ and venous pressure $\left(P_{V}\right)$ were measured by transducers. Intra-articular fluid pressure $\left(P_{J}\right)$ was measured via an intra-articular cannula. An infusion reservoir (IR) of Krebs' solution controlled $P_{J}$. Absorption rate was recorded in the steady state $\left(\dot{Q}_{S}\right)$ by a drop counter (DC). region, connected to a SE 100/WG pressure transducer. $P_{J}$ was set by the height of an infusion reservoir of Krebs' solution connected to the joint cavity by a second IA cannula (Fig. 1). Most experiments were at $\mathrm{P}_{\mathrm{J}} 18 \mathrm{cmH}_{2} \mathrm{O}$, a pressure typical of a moderate effusion. Dilution of the endogenous synovial fluid $(\sim 24 \mu \mathrm{l})^{4}$ by Krebs' solution reduced the IA COP to less than $2 \mathrm{cmH}_{2} \mathrm{O}$ (osmometry of aspirates).

TRANS-SYNOVIAL FLOW ( $\left.\dot{\mathrm{Q}}_{S}\right)$

A drop counter between the infusion reservoir and IA cannula recorded the flow of Krebs' solution into the joint cavity. Published studies with nonabsorbed oils at $18 \mathrm{cmH}_{2} \mathrm{O}$ showed that joint expansion (creep) contributed only $10 \%$ of the inflow at 15-20 min and declined slowly (e.g., $4 \%$ at $80 \mathrm{~min}){ }^{3}$ The creep component was subtracted by analysing differences between inflow within two to three minutes of a step in COP. Observations began at $20 \mathrm{~min}$ and continued for $120-180 \mathrm{~min}$.

THE VASCULAR PERFUSATE

The perfusate comprised red cells (human group $\mathrm{O}$, $\mathrm{Rh}$ negative) resuspended in solutions of serum albumin (Sigma Chemicals, Poole, Dorset, England; bovine Cohn fractionV; 10-120 g/l Krebs' solution, $\mathrm{pH} 7 \cdot 35)$. COP was 5-80 $\mathrm{cmH}_{2} \mathrm{O}$. Packed cell volume was $30-40 \%$. In one study red cells were resuspended in whole human plasma, diluted by Krebs' solutions or concentrated by evaporation, and dialysed to isotonicity. The two extracorporeal circuits contained perfusates of different COP to facilitate abrupt changes in intravascular COP. Timed samples of venous effluent established that COP in the vasculature of the preparation achieved $90 \%$ of its final value within 100 seconds of switching tap A. Two minutes were allowed before the trans-synovial flow change was analysed.

Oxygen consumption was optimal at perfusion rates of greater than $15 \mathrm{ml} / \mathrm{min} .{ }^{3}$ Vasodilator and blocking agents prevented active changes in vascular resistance (isoprenaline $20 \mu \mathrm{g} / 100 \mathrm{ml}$; phentolamine $0.75 \mathrm{mg} / 100 \mathrm{ml}$; papaverine $1 \mathrm{mg} / 100 \mathrm{ml}$ ).

\section{COLLOID OSMOTIC PRESSURE OF PERFUSATE $\left(\pi_{p}\right)$}

Venous plasma COP was measured with an electronic osmometer ${ }^{5}$ fitted with an Amicon PM 10 semipermeable membrane (cut off mol. wt 10000 ). Several commercial samples of fraction $\mathrm{V}$ albumin gave COPs which did not conform to the much used polynomial of Landis and Pappenheimer. ${ }^{6}$ This may be of practical significance for other investigators; COP should be measured rather than calculated from concentration.

\section{Results}

EFFECT OF PLASMA COP ON

TRANS-SYNOVIAL FLOW

Switching from a vascular perfusate of low COP to one of high COP caused a marked rise in rate of fluid absorption from the joint cavity at $18 \mathrm{cmH}_{2} \mathrm{O}$ (Fig. 2). This reversed on switching back to a low COP. The response was a graded, quantitative one 


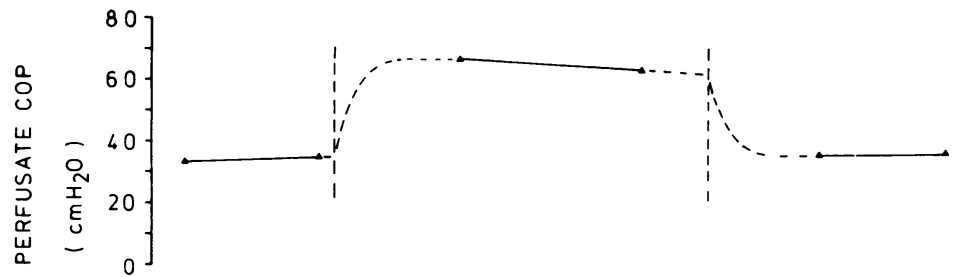

Fig. 2 Effect of perfusate colloid osmotic pressure (COP) on trans-synovial flow (calculated over $\stackrel{\varnothing}{\triangle}$

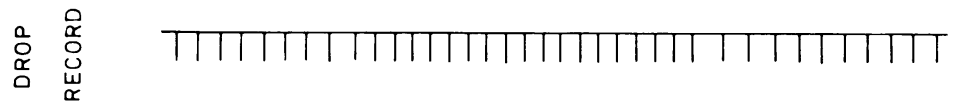

2 drops from drop record: 1 drop $=0$ $13 \cdot 4 \mu l)$. At $H$, perfusion was switched to the second
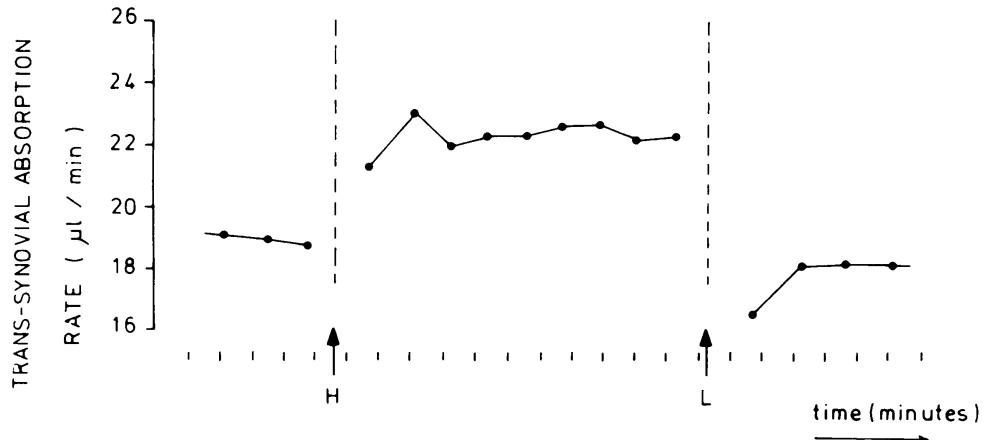

extracorporeal circuit, primed with blood of higher COP. The dashed line between the measured values of COP represents the time course of $C O P$ as determined by rapid sampling in control studies. At $L$ perfusion was switched back to the original circuit (blood of lower COP).

(Figs 3 and 5). The relation between change in trans-synovial flow and change in plasma COP for 16 joints was well fitted by a straight line of slope $0.20\left(\mathrm{SE} 0.01\right.$ ) $\mu \mathrm{l} / \mathrm{min} / \mathrm{cmH}_{2} \mathrm{O}$ (least squares fit: $n=83$; correlation coefficient $=0.94 ; p<0.001$ ). The regression line passed virtually through the origin (intercept $=-0.41 \mu \mathrm{l} / \mathrm{min}$ ), indicating that the effects of increasing or decreasing COP were symmetrical (Fig. 5).
COMPARISON OFEFFICACY OF COP CHANGES AND BLOOD PRESSURE CHANGES

A rise in synovial capillary blood pressure reduceco the rate of fluid absorption (Fig. 3). ${ }^{3}$ Are the effect $\$ \frac{1}{2}$ of plasma COP $\left(\pi_{p}\right)$ and capillary pressure $\left(\mathrm{P}_{\mathrm{C}}\right)$ equal and opposite, or is there a difference ing magnitude as well as direction? In five joints the response of trans-synovial flow to albumin COP was compared with the response to capillary hydraulici

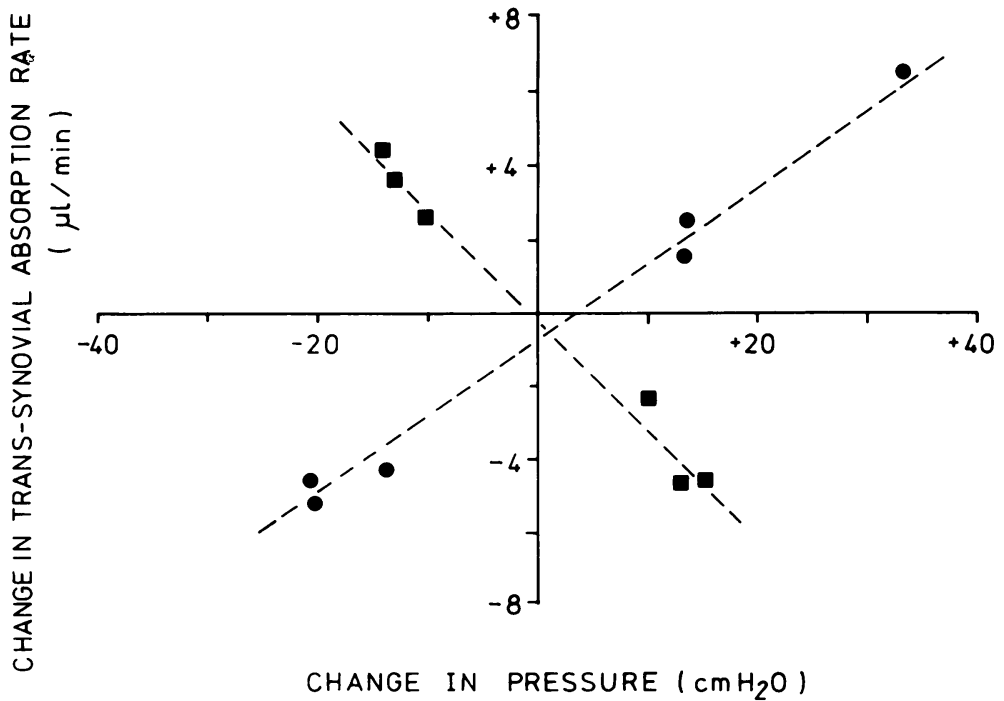

Fig. 3 The effect of perfusate colloid (albumin) osmotic pressure on the rate of absorption of Krebs solution from a joint cavity (Q) compared with the effect of mean capillary blood pressure in the same joint (घ). Mean capillary pressures were calculated from arterial pressure, venous pressure, and synovial pre-to postcapillary resistance ratio ( $3 \cdot 3$ for this joint). The effects were of course opposite in direction; but note also that the response to albumin $C O P$ (slope of dashed regression line $0 \cdot 21$ $\left(\mathrm{SE} \mathrm{0.015)} \mathrm{\mu l} / \mathrm{min} / \mathrm{cmH}_{2} \mathrm{O}\right.$ ) was less.? than the response to capillary pressure (slope -0.29 (SE 0.015) $\left.\mu \mathrm{l} / \mathrm{min} / \mathrm{cmH}_{2} \mathrm{O}\right)(p<0 \cdot 01, \mathrm{t}$ test $)$. The ratio of the two slopes (the efficacy of the colloid) is 0.78 for this joint.

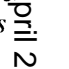


pressure, altered by step changes in arterial or venous pressure. ${ }^{3}$ Hydraulic pressure had a relatively greater effect on exchange than did an equal change in COP (Fig. 3). The sensitivity of transsynovial flow to COP (slope $\mathrm{dQ}_{\mathrm{S}} / \mathrm{d} \pi_{\mathrm{p}}$ ) was less than its sensitivity to capillary hydraulic pressure (slope $\mathrm{dQ}_{\mathrm{S}} / \mathrm{dP}_{\mathrm{C}}$ - although of course of opposite sign. This difference was observed consistently in all five joints. The ratio of $\mathrm{d} \dot{\mathrm{Q}}_{\mathrm{S}} / \mathrm{d} \pi_{\mathrm{p}}$ to $\mathrm{dQ} \dot{\mathrm{Q}}_{\mathrm{S}} / \mathrm{dP}_{\mathrm{C}}$ averaged 0.78 (SEM 0.06) $(n=5)$, i.e., on average serum albumin exerted only $78 \%$ of its potential COP across the blood-joint interface-see 'Discussion'.

\section{OSMOTIC TRANSIENTS GENERATED BY}

SMALL SOLUTES

Edlund reported that intravenous injection of hypertonic sucrose solution promotes fluid absorption from the joint cavity. ${ }^{7}$ We reinvestigated Edlund's intriguing observation by five hyperosmolar perfusions in four joints, after the effect of COP had been determined. The hyperosmolar fluids were $1 \mathrm{M}$ glucose (three experiments), $1 \mathrm{M}$ sucrose (one experiment), and $0.5 \mathrm{M} \mathrm{NaC1}$ (one experiment) in $20 \mathrm{~g}$ albumin/l Krebs' solution.

Upon switching from control perfusate (red cells in $20 \mathrm{~g}$ albumin/l Krebs' solution) to hyperosmolar perfusate, the trans-synovial absorption rate climbed rapidly and steeply, peaking at several times control level (Fig. 4). Absorption then de- cayed rapidly, with an average half life $\left(t_{1 / 2}\right)$ of $28 \mathrm{~s}$ for glucose transients $(60 \mathrm{~s}$ sucrose; $17 \mathrm{~s} \mathrm{NaCl})$. The rapidity of decay $\left(1 / t_{1 / 2}\right)$ correlated with the solute diffusion coefficients, which are in the ratio 2.85:1.29:1.00 for $\mathrm{NaCl}$ :glucose:sucrose. ${ }^{8}$ Thus rapid outward diffusion of test solute into synovial interstitium and joint cavity was dissipating the osmotic gradient across the capillary wall.

Evidence that test solute accumulated in the extracapillary space was obtained upon switching back to isotonic perfusate. This caused a rapid decline in absorption rate to zero followed by a transient rise in intra-articular fluid pressure, showing that trans-synovial flow had reversed and fluid was being drawn osmotically into the joint cavity. The same phenomena, an initial osmotic transient then a reversed osmotic transient, were demonstrated in vitro by applying first a hyperosmolar glucose solution and then an isosmolar solution to the PM10 membrane of the osmometer.

COMPARISON OF OSMOTIC EFFICACY OF PROTEIN AND SMALL SOLUTES

Expressing osmolarity in $\mathrm{cmH}_{2} \mathrm{O}$ and allowing for non-ideality in hypertonic solutions, ${ }^{8}$ the maximum increase in absorption rate per $\mathrm{cmH}_{2} \mathrm{O}$ increase in arterial osmolarity $\left(\mathrm{d} \dot{Q}_{\max } / \mathrm{d} \pi_{\mathrm{a}}\right)$ averaged $3 \cdot 1 \times 10^{-3}$ $\mu \mathrm{l} / \mathrm{min} / \mathrm{cmH}_{2} \mathrm{O}$ for glucose $\left(3 \cdot 6 \times 10^{-3} \mu \mathrm{l} / \mathrm{min} /\right.$ $\mathrm{cmH}_{2} \mathrm{O}$ for sucrose; $4.7 \times 10^{-3} \mu \mathrm{l} / \mathrm{min} / \mathrm{cmH}_{2} \mathrm{O}$ for
DROP

RECORD

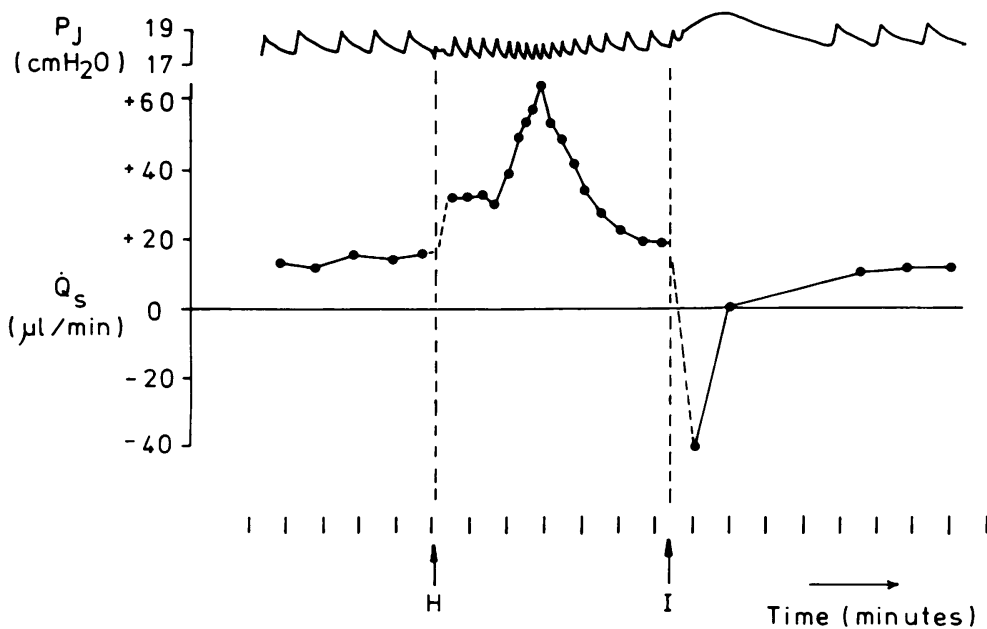

Fig. 4 Effect of perfusion of synovial microcirculation with hyperosmolar glucose solution upon trans-synovial absorption of Krebs' solution $\left(Q_{S}\right)$, calculated from drop record (1 drop $-13.4 \mu \mathrm{l})$. At $\mathrm{H}$, perfusion was switched from red cells in $20 \mathrm{~g}$ albumin/l Krebs' solution to $20 \mathrm{~g}$ albumin plus $1 \mathrm{~mol}$ glucosell Krebs' solution. Absorption rate increased transiently by over fourfold. The initial low hump may have been due to transient disturbance of perfusion pressure on switching circuits or to heterogeneity of synovial microvascular transit times, or both. On switching back to isotonic perfusate at 1 , drop fall ceased and absorption reversed to filtration into the joint cavity, as is evident from the rising intra-articular pressure $\left(P_{J}\right)$. The point plotted for $-Q_{S}(-41 \mu \mathrm{l} / \mathrm{min})$ was obtained from the initial rate of pressure increase $\left(0.85 \mathrm{cmH}_{2} \mathrm{O} / \mathrm{min}\right)$ and elastance $\left(\mathrm{dP} / \mathrm{dV}=20.6 \mathrm{cmH}_{2} \mathrm{O} / \mathrm{ml}\right.$ at $\left.18 \mathrm{cmH}_{2} \mathrm{O}\right) .^{16}$ 


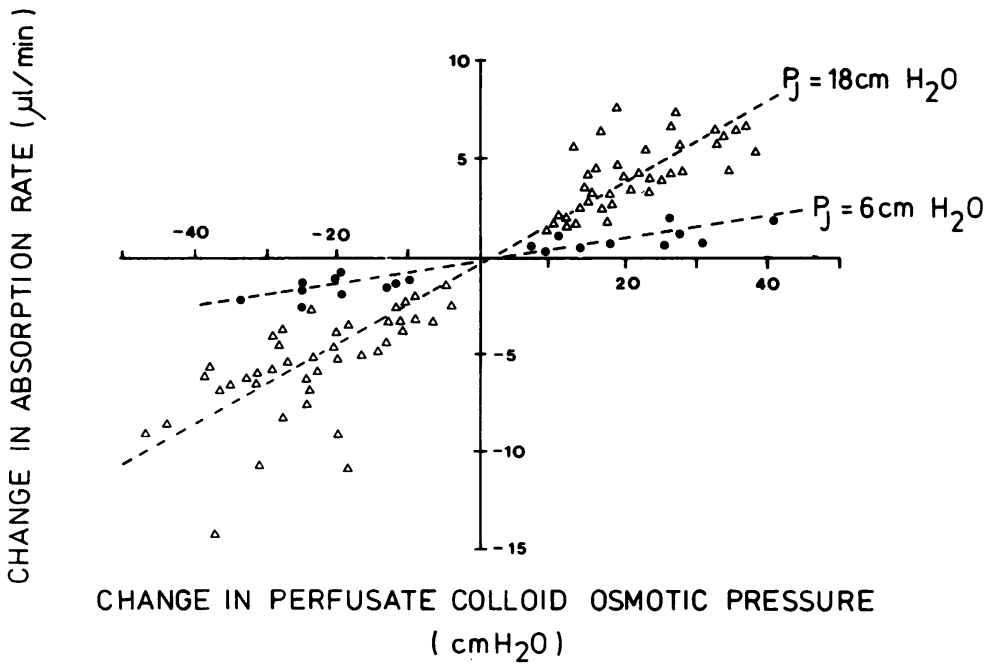

Fig. 5 Changes in trans-synovial flow produced by 83 changes in synovial microvascular COP in 16 knees at $18 \mathrm{cmH}_{2} \mathrm{O}$ intra-articular pressure $(\triangle)$. The dashed regression line through these data has a slope of $\omega$ 0.20 (SE 0.01) $\mu \mathrm{l} / \mathrm{min} / \mathrm{cmH}_{2} \mathrm{O}$. The $\overrightarrow{0}$ effect of $C O P$ on trans-synovial flow at a lower intra-articular pressure $(6 \vec{\omega}$ $\mathrm{CmH}_{2} \mathrm{O}$ ) was less marked (O); the regression slope was 0.051 (SE 0.007) $\mathrm{ul} / \mathrm{min} / \mathrm{cmH}_{2} \mathrm{O}(n=20$, five joints). The difference in effect is 0 highly significant $(p<0.001, t$ test $)$.

$\mathrm{NaCl})$. Thus even the peak osmotic efficacy of small solute was only $1 / 50$ th-1/100th that of albumin (see earlier). The ratio of $d \dot{Q}_{\max } / \mathrm{d} \pi_{a}$ (osmotic effect of small solute) to $\mathrm{dQ}_{\mathrm{S}} / \mathrm{dP}_{\mathrm{C}}$ (effect of capillary blood pressure) in the same joint averaged 0.013 for glucose $(0.010$ for $\mathrm{NaCl} ; 0.025$ for sucrose).

OSMOTIC EFFECT OF INTRAVASCULAR

COLLOID AT HIGH AND LOW

INTRA-ARTICULAR PRESSURE ( $\left.P_{J}\right)$

The above experiments were carried out at $\mathrm{P}_{\mathrm{J}}=18$ $\mathrm{cmH}_{2} \mathrm{O}$, typical of a joint with a moderate effusion. The hydraulic permeability of the blood-joint barrier may change, however, with intra-articular pressure. ${ }^{9}{ }^{10}$ Further perfusions were therefore carried out at a lower intra-articular pressure, $\mathrm{P}_{\mathrm{J}}=6$ $\mathrm{cmH}_{2} \mathrm{O}$, in five joints. The trans-synovial absorption rate was again a linear function of plasma COP (correlation coefficient $0 \cdot 89 ; n=20 ; p<0 \cdot 001$ ) (Fig. $5)$. The slope of the relation, however, was much less steep-only $0.051 \mu \mathrm{l} / \mathrm{min} / \mathrm{cmH}_{2} \mathrm{O}$ compared with $0.25 \mu \mathrm{l} / \mathrm{min} / \mathrm{cmH}_{2} \mathrm{O}$ at $\mathrm{P}_{\mathrm{J}}=18 \mathrm{cmH}_{2} \mathrm{O}$ in the same five joints $(p<0.001, t$ test; see 'Discussion').

\section{Discussion}

The linear proportional relation between plasma COP and trans-synovial flow established unequivocally the applicability of Starling's hypothesis to the synovial system. A number of other interesting points also emerged.

OSMOTIC REFLECTION COEFFICIENT OF BLOOD-JOINT BARRIER TO ALBUMIN Albumin exerted only $78 \%$ of ịts osmotic potential across the blood-joint interface. The ratio of osmotic pressure across a test membrane to that across $\mathrm{a} \vec{\circ}$ perfect semipermeable membrane (here PM10) is by. definition the 'osmotic reflection coefficient', $\sigma .{ }^{11}$ Its value can range from 0 (no reflection of solute by乏 pore) to 1 (total exclusion of solute by pore). This is one of the fundamental parameters describing a passive membrane, because it characterises molecu-D lar selectivity and equivalent pore size. The synovial data indicated that $\sigma_{\text {albumin }}$ across the blood-joint barrier averaged 0.78 (SEM 0.06). A value of $<1.05$ is in keeping with the known slight permeability tof albumin. ${ }^{412}$ Equivalent pore size can be evaluated from reflection coefficients. In terms of a homopor $-\frac{\overline{2}}{2}$ ous neutral membrane model a $\sigma$ of 0.78 for a soluteo of diffusion radius $3.6 \mathrm{~nm}$ (albumin) implies a pore radius of 5.5-6.3 nm. ${ }^{11}$ A better physical representa-ô tion of the blood-joint barrier, however, may be a fibre matrix model. ${ }^{13}$

The characterisation of reflection coefficients? across the blood-joint barrier is of fundamenta importance not only because of the clues provided about pathway dimensions but also because a fall incr $\sigma_{\text {albumin }}$ is probably crucial in the pathogenesis off inflammatory joint effusions. ${ }^{14}$

OSMOTIC EFFECT OF SMALL SOLUTES

The hyperosmolar perfusions confirmed Edlund's observation of enhanced fluid absorption buts showed that the effects were not sustained. Indeed the rapid dissipation of the osmotic gradient across the capillary wall was dramatic evidence of the hight permeability of the blood-joint barrier to small solutes. Nevertheless the osmotic reflection coeffi cient to small solutes was clearly greater than zero? 
A. minimal value for $\sigma$ is given by the ratio $\mathrm{d} \dot{\mathrm{Q}}_{\max } / \mathrm{d} \pi_{\mathrm{a}}$ to $\mathrm{dQ} \dot{\mathrm{Q}}_{\mathrm{S}} / \mathrm{dP}$, giving $\sigma_{\mathrm{NaCl}} \geqslant 0 \cdot 010, \sigma_{\text {glucose }}$ $\geqslant 0.013, \sigma_{\text {sucrose }} \geqslant 0.025$. It is stressed, however, that these values are lower limits. Owing to rapid diffusion of solute out of the capillary, the mean osmotic gradient across the capillary wall was almost certainly less than the known arterial osmotic pressure by the time of peak flow (30-60 s), leading to underestimation of $\sigma$.

Although changes in plasma osmolarity in vivo are much smaller than those used here, significant transient effects on synovial exchange could nevertheless arise. After haemorrhage, for example, plasma glucose is increased by accelerated hepatic glycogenolysis, raising plasma osmolarity by up to $25 \mathrm{mmol}\left(657 \mathrm{cmH}_{2} \mathrm{O}\right) .{ }^{15}$ For $\sigma_{\text {glucose }} \geqslant 0.013$ this means an increased osmotic pressure of $\geqslant 8.5$ $\mathrm{cmH}_{2} \mathrm{O}(\geqslant 25 \%$ of plasma COP) exerted transiently across the blood-joint barrier. Such transients may prove important to understanding short term fluctuations in synovial volume.

\section{DEPENDENCE OF SYNOVIAL HYDRAULIC PERMEABILITY ON INTRA-ARTICULAR PRESSURE}

The flow generated by unit change in plasma COP was about four times greater at $18 \mathrm{cmH}_{2} \mathrm{O}$ than at 6 $\mathrm{cmH}_{2} \mathrm{O}$ intra-articular pressure. This was not owing to any breakdown in the semipermeable nature of the barrier because $\sigma_{\text {albumin }}$ was high $(0 \cdot 78)$ at 18 $\mathrm{cmH}_{2} \mathrm{O}$. The flow generated by unit change in synovial blood pressure increased by a similar factor between 6 and $18 \mathrm{cmH}_{2} \mathrm{O}$ intra-articular pressure. ${ }^{10}$ Both effects can be explained by an increase in the hydraulic permeability of the synovial intima (second component of the barrier, in series with capillary wall) as intra-articular pressure rises-the 'yield phenomenon'. ${ }^{10} \mathrm{~A}$ yielding of intimal resistance to flow at pathological joint pressures could greatly influence the kinetics of joint effusion formation and resolution.
This research was supported by a grant from the Arthritis and Rheumatism Council of Great Britain.

\section{References}

1 Bauer M, Ropes $\mathrm{M} \mathrm{W}$, Waine $\mathrm{H}$. The physiology of articular structures. Physiol Rev 1940; 20: 272-312.

2 Palmer D G, Myers D B. Some observations of joint effusions. Arthritis Rheum 1968; 11: 745-55.

3 Knight A D, Levick J R. The influence of blood pressure on trans-synovial flow in the rabbit. J Physiol (Lond) 1984; 349: 27-42.

4 McDonald J N, Levick J R, Knox P. Forces governing fluid exchange in major limb joints of rabbits. Scand $J$ Rheumatol [Suppl] 1986; 60: A70.

5 Hansen A T. A self-recording electronic osmometer for quick, direct measurements of colloid osmotic pressures in small samples. Acta Physiol Scand 1961; 53: 197-213.

6 Landis E M. Pappenheimer J R. Exchange of substances through capillary walls. In: Hamilton W F, ed. Handbook of physiology, Section 2, Circulation. Vol II. Washington DC: American Physiology Society, 1963: 961-1034.

7 Edlund T. Studies on the absorption of colloids and fluid from rabbit knee joints. Acta Physiol Scand [Suppl] 1949; 62: 1-108.

8 Weast R C. Handbook of chemistry and physics. 56th ed. Cleveland: CRC Press, 1975.

9 Levick J R. The influence of intra-articular hydrostatic pressure on trans-synovial fluid movement and on capsular expansion in rabbit knee joints. J Physiol (Lond) 1979; 289: 69-82.

10 Knight A D, Levick J R. Effects of fluid pressure on the hydraulic conductance of interstitium and fenestrated endothelium in the rabbit knee. J Physiol (Lond) 1985; 360: 311-32.

11 Curry F E. Mechanics and thermodynamics of transcapillary exchange. In: Renkin E M, Michel C C, eds. Handbook of physiology, Section 2, The cardiovascular system. Vol IV, part I: The microcirculation. Bethesda, Maryland: American Physiology Society, 1984: 309-74.

12 Levick J R. Permeability of rheumatoid and normal human synovium to specific plasma proteins. Arthritis Rheum 1981; 24: $1550-60$.

13 Levick J R, Smaje L H. An analysis of the permeability of a fenestra. Microvasc Res (in press).

14 Levick J R. Synovial fluid dynamics. In: Marouds A, Holborow E J, eds. Studies in joint disease. Vol 2. London: Pitman Medical, 1983: 153-240.

15 Järhult J, Holmberg J, Lundvall J, Mellander S. Hyperglycaemic and hyperosmolar responses to graded haemorrhage. Acta Physiol Scand 1976; 97: 470-5.

16 Knight A D, Levick J R. Pressure-volume relationships above and below atmospheric pressure in the synovial cavity of the rabbit knee. J Physiol (Lond) 1982; 328: 403-20. 